\title{
48. SEISMIC VELOCITIES AT ELEVATED PRESSURES OF IGNEOUS ROCKS FROM THE MARIANA TROUGH AND FORE-ARC REGION, DEEP SEA DRILLING PROJECT LEG $60^{1}$
}

\author{
N. I. Christensen, S. C. Blair, R. C. Prior, and J. P. Schultz, Department of Geological Sciences and \\ Graduate Program in Geophysics, University of Washington, Seattle, Washington
}

\section{INTRODUCTION}

The Deep Sea Drilling Project, in addition to providing valuable information on the history and processes of development of the ocean, has significantly contributed to our knowledge of the chemical and physical nature of the upper oceanic crust. Among the important physical properties of the crust are its seismic velocity and structure, the interpretation of which requires laboratory studies of seismic velocities in oceanic rocks.

Velocities that have been reported for rocks from the Deep Sea Drilling Project include shipboard measurements at low pressures using the Hamilton Frame velocimeter, as well as land-based laboratory measurements at elevated confining pressures. The latter velocities are particularly useful for comparison with seismic refraction data from Layers 2 and 3, since laboratory velocities often show a pronounced change with confining pressure.

Velocities reported at elevated pressures for rocks from the Deep Sea Drilling Project are summarized by Christensen and Salisbury (1975) and Christensen (1977). To date most of the measurements have been made on basalts recovered from main ocean basins, and only few data are available for rocks from back-arc basins. Just as the petrology of main ocean basin and back-arc basin rocks may differ (Hawkins, 1977), the physical properties may show significant differences for rocks from these two tectonic provinces. To examine this question, we have studied a number of basalts obtained on DSDP Leg 60 from Sites 454 and 458 in the Mariana Trough and fore-arc region (Fig. 1). In addition, the availability of downhole logs for Site 454 increases the importance of laboratory velocity studies under in situ conditions.

\section{TECHNIQUE AND DATA}

Compressional wave velocities (Table 1) have been measured as a function of confining pressure using the pulse transmission method (Birch, 1960). The samples are $2.5 \mathrm{~cm}$ in diameter with average lengths of $2.0 \mathrm{~cm}$, and they were saturated prior to being jacketed with heavy copper foil. Copper screen was used between each jacket and sample to reduce pore pressure buildup. Silver paint on the core ends maintained electrical continuity between the jacket and transducers. Due to the high vesicularities of the basalt samples, the cores were delicate and maximum confining pressures were held to $3.0 \mathrm{kbar}$. Unfortunately, even with this precaution, some samples were damaged during compressional wave runs. For these samples, velocities are

\footnotetext{
${ }^{1}$ Initial Reports of the Deep Sea Drilling Project, Volume 60.
}

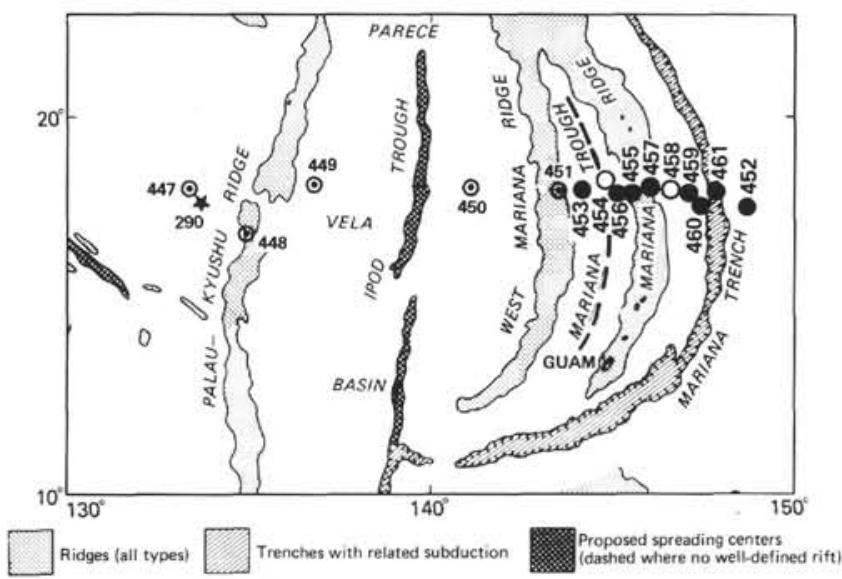

Figure 1. Locations of Sites 454 and $458(0)$ plus other Leg 60 sites $(\bullet)$.

reported only for increasing pressures. Wet-bulk densities $(\varrho)$ were obtained from core dimensions and weights.

Sample 458-32-3, 57-59 cm was not damaged, enabling shear wave $\left(V_{s}\right)$ velocities to be obtained on a second pressure run. It was thus possible to calculate the Poisson's ratio $(\sigma)$, bulk modulus $(K)$, shear modulus $(\mu)$, Young's modulus $(E)$, and Lame's constant $(\lambda)$, for this sample at varying pressures (Table 2), using the equations by Birch (1961). An iterative routine which corrected for dimensional changes at higher pressures was used for the calculations.

\section{DISCUSSION}

Compressional wave velocities and one shear velocity at $0.5 \mathrm{kbar}$ confining pressure are plotted against bulk density in Figure 2. Also incorporated into Figure 2 are measured compressional and shear wave velocities and velocity-density relations for DSDP basalts at $0.5 \mathrm{kbar}$ as reported by Christensen and Salisbury (1975). The nonlinear solutions are defined by equations:

$$
\begin{aligned}
& V_{p}=2.33+0.081 \varrho^{3.63} \\
& V_{s}=1.33+0.011 \varrho^{4.85} .
\end{aligned}
$$

The values of $V_{p}$ for the four samples from Site 458 follow the predicted trends closely, as does the shear wave velocity of Sample $458-32-3,57-59 \mathrm{~cm}$. The two basalts studied from Site 454 exhibit compressional wave velocities higher than most basalts of the same density; considering the difficulty of making measurements on such fragile samples, however, the agreement between predicted and observed velocities is quite good. The 
Table 1. Bulk densities and compressional wave velocities.

\begin{tabular}{lccccccccc}
\hline \multicolumn{1}{c}{$\begin{array}{c}\text { Sample } \\
\text { (interval in cm) }\end{array}$} & $\begin{array}{c}\text { Bulk } \\
\text { Density }\end{array}$ & 0.2 & 0.4 & 0.6 & 0.8 & 1.0 & 2.0 & 3.0 \\
\hline $454-5-3,30-32$ & 2.412 & 4.62 & 4.66 & 4.69 & 4.71 & 4.73 & 4.79 & 4.82 \\
$454-11-4,15-18$ & 2.280 & 4.28 & 4.35 & 4.41 & - & - & - & - \\
$458-28-1,120-121$ & 2.189 & 3.74 & 3.76 & 3.77 & 3.79 & 3.80 & 3.86 & 3.92 \\
$458-32-3,57-59$ & $2.379 \mathrm{a}$ & 3.94 & 4.10 & 4.22 & 4.31 & 4.38 & 4.56 & 4.66 \\
$458-37-1,25-27$ & 2.290 & 4.01 & 4.03 & 4.04 & 4.05 & 4.08 & 4.10 & 4.17 \\
$458-40-1,60-61$ & 2.176 & 3.19 & 3.21 & 3.26 & 3.26 & 3.29 & 3.38 & 3.44 \\
\hline
\end{tabular}

a Dry-bulk density.

Table 2. Elastic constants and shear wave velocities of Sample $458-32-3,57-59 \mathrm{~cm}$ at varying pressures.

\begin{tabular}{cccccccc}
\hline $\begin{array}{c}\text { Pressure } \\
\text { (kbar) }\end{array}$ & $\begin{array}{c}V_{s} \\
(\mathrm{~km} / \mathrm{s})\end{array}$ & $V_{p} / V_{s}$ & $\sigma$ & $\begin{array}{c}K \\
(\mathrm{Mb})\end{array}$ & $\begin{array}{c}\mu \\
(\mathrm{Mb})\end{array}$ & $\begin{array}{c}E \\
(\mathrm{Mb})\end{array}$ & $\begin{array}{c}\lambda \\
\mathrm{Mb})\end{array}$ \\
\hline 0.2 & 1.86 & 2.12 & 0.36 & 0.26 & 0.08 & 0.22 & 0.20 \\
0.4 & 2.03 & 2.02 & 0.34 & 0.27 & 0.10 & 0.26 & 0.21 \\
0.6 & 2.13 & 1.92 & 0.33 & 0.28 & 0.11 & 0.29 & 0.21 \\
0.8 & 2.20 & 1.95 & 0.32 & 0.29 & 0.12 & 0.31 & 0.21 \\
1.0 & 2.26 & 1.91 & 0.32 & 0.29 & 0.12 & 0.32 & 0.21 \\
2.0 & 2.41 & 1.90 & 0.31 & 0.31 & 0.14 & 0.36 & 0.22 \\
3.0 & 2.48 & 1.87 & 0.30 & 0.32 & 0.15 & 0.38 & 0.22 \\
\hline
\end{tabular}

measured velocities $\left(V_{p}=3.2-4.7 \mathrm{~km} / \mathrm{sec}, V_{s}=2.1\right.$ $\mathrm{km} / \mathrm{s}$ ) are low for basaltic rocks, and this may be relevant to interpretation of seismic surveys in the area.

Our data for Sample 454-11-4, 15-18 cm can be compared with shipboard data for Sample 454-11-4, 37-43 $\mathrm{cm}$ and with logging data from the same site.

The Hamilton Frame velocity of $4.28 \mathrm{~km} / \mathrm{s}$ at atmospheric pressure is slightly higher than the zeropressure projection of our measurements on Sample $454-11-4,15-18 \mathrm{~cm}$. The density determination of 2.33 $\mathrm{g} / \mathrm{cm}^{3}$ by GRAPE analysis is also slightly higher. Our density value is in agreement with values reported by the compensated density $\log$ at a sub-bottom depth of 126.65 meters, while the sonic log velocity at this depth $(2.7 \mathrm{~km} / \mathrm{s})$ is much lower than laboratory values. The lower acoustic log velocities indicate that crack porosity on a scale larger than our sample size is a significant physical parameter in the upper crust at this location.

\section{ACKNOWLEDGMENTS}

This investigation was supported by the Office of Naval Research, contract N-000-14-75-C-0502. The manuscript was reviewed by M. H. Salisbury and D. M. Johnson.

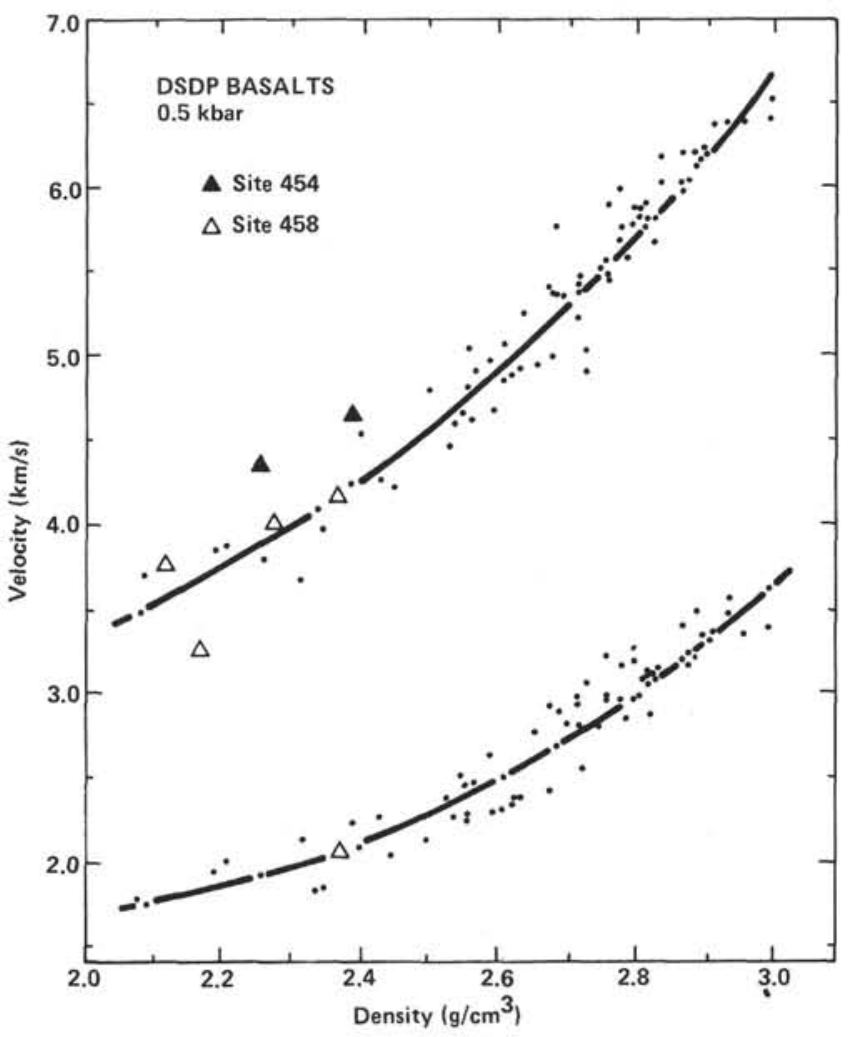

Figure 2. Compressional $\left(V_{-p}\right)$ and shear $\left(V_{s}\right)$ wave velocities versus densities at $0.5 \mathrm{kbar}$ confining pressure. Small dots are other DSDP basalts (Christensen and Salisbury, 1975).

\section{REFERENCES}

Birch, F., 1960. The velocity of compressional waves in rocks to 10 kilobars, 1. J. Geophys. Res., 65:1083-1102.

1961. The velocity of compresional waves in rocks to 10 kilobars, 2. J. Geophys. Res., 66:2199-2224.

Christensen, N. 1., 1977. Seismic velocities and elastic moduli of igneous and metamorphic rocks from the Indian Ocean. In Heirtzler, J. R., Bolli, H. M., Davies, T. A., Saunders, J. B., and Sclater, J. G. (Eds.), Indian Ocean Geology and Biostratigraphy: Washington (American Geophysical Union), pp. 279-299.

Christensen, N. I., and Salisbury, M. H., 1975. Structure and constitution of the lower ocean crust. Reviews of Geophysics and Space Physics, 13:57-86.

Hawkins, J. W., 1977. Petrologic and geochemical characteristics of marginal basin basalts. In Talwani, M., and Pitman, W. C. (Eds.), Island Arcs, Deep Sea Trenches and Back-Arc Basins: Maurice Ewing Series I: Washington (Am. Geophysical Union), pp. 335-366. 